\title{
Chronic interstitial lung disease (ChILD) in childhood
}

\author{
M N Lucas ${ }^{1}$, H M K N Hathlahawatta ${ }^{2}$, R Seneviratne ${ }^{3,}$ D Samarage
}

Sri Lanka Journal of Child Health, 2008; 37: 129-130

(Key words: Chronic interstitial lung disease in childhood, ChILD)

\section{Introduction}

Chronic interstitial lung disease (ChILD) in children is a diverse group of conditions primarily involving the alveoli and perialveolar tissue, leading to a derangement of gas exchange, restrictive lung physiology and diffuse infiltrates on radiographs ${ }^{1}$. To date this disorder is found to be rare in children and neither incidence or prevalence is known. This is the first reported case in Sri Lanka.

\section{Case Report}

A $1 \frac{1}{2}$ year old girl, a product of incest, was admitted on $13^{\text {th }}$ of March, 2007 with a history of cough, cold and shortness of breath of 2 days duration. On examination, she weighed $5 \mathrm{~kg}$ and had severe failure to thrive, dyspnoea, tachypnoea (respiratory rate $70-80 / \mathrm{min}$ ), intercostal and subcostal recession, flaring alae nasi, bilateral rhonchi and crepitations. She was treated with intravenous antibiotics for 7 days, oxygen for 10 days and regular nebulisation. She responded slowly and was off oxygen in 10 days. Her lungs were clear but tachypnoea persisted. In 5 days time there was worsening of her symptoms and she developed fever, became ill and oxygen dependant with another respiratory infection. With similar treatment she recovered after about a week but the tachypnoea persisted. There was no contact history of tuberculosis.

Chest $\mathrm{X}$ rays done 2 weeks apart showed persistent infiltration of bilateral lung fields (Figures 1 and 2).

${ }^{1}$ Registrar, ${ }^{2}$ Senior Registrar in Paediatrics, Colombo South Teaching Hospital, ${ }^{3}$ Senior Lecturer \& Head, ${ }^{4}$ Senior Lecturer, Department of Paediatrics, University of Sri Jayawardenapura.

(Received on 15 August 2007. Accepted on 23 August 2007)

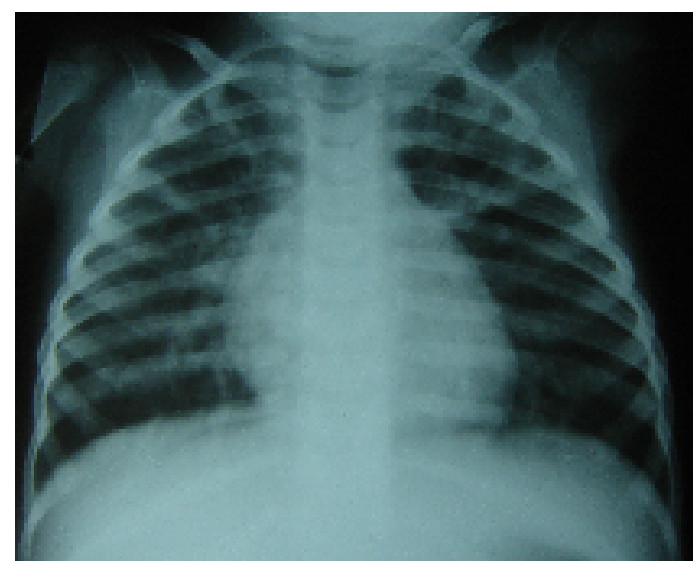

Figure 1 Initial chest $x$-ray showing bilateral lung infiltration

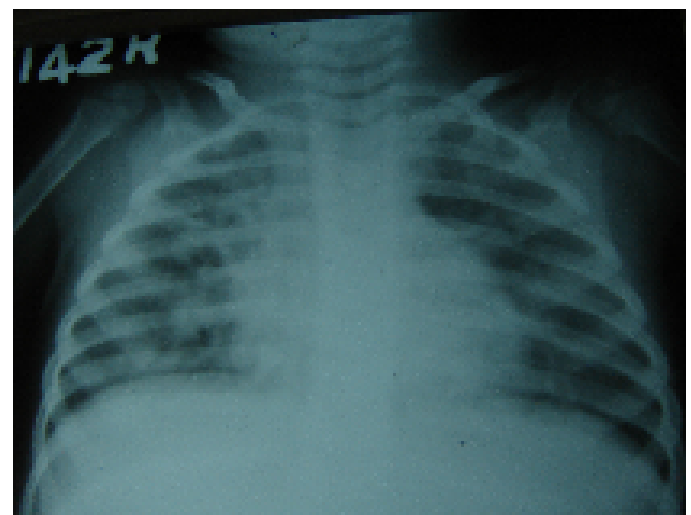

Figure 2 Chest X-ray 2 weeks later showing persistent infiltration

ESR was high $\left(80-85 \mathrm{~mm} 1^{\text {st }} \mathrm{hr}\right)$ at times of exacerbation and normal $\left(6-8 \mathrm{~mm} 1^{\text {st }} \mathrm{hr}\right)$ in between. High Resolution CT (HRCT) scan of chest showed diffuse ground glass appearance with thickened interstitium (Figure 3). Antibody to Human Immunodeficiency Virus was negative. Mantoux test as well as gastric aspirate for acid fast bacilli were negative. 


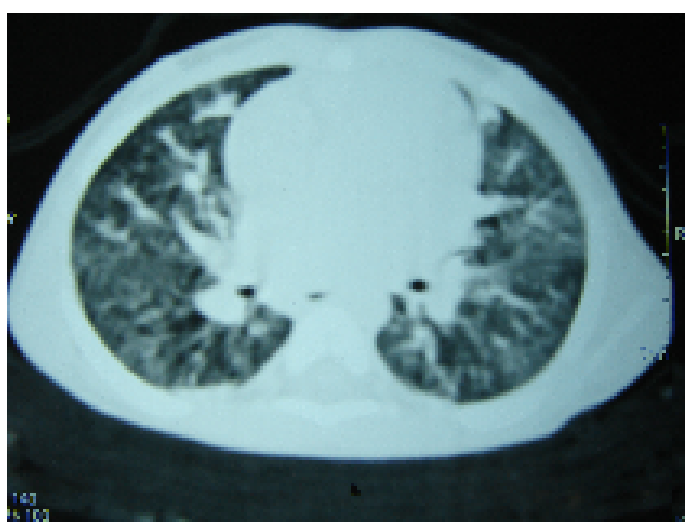

Figure 3 High resolution CT chest showing diffuse ground glass appearance with thickened interstitium

Based on the above chest $\mathrm{X}$ ray and HRCT chest findings she was diagnosed to have chronic interstitial lung disease and treatment was initiated with steroids. Treatment was commenced with prednisolone $2 \mathrm{mg} / \mathrm{kg}$ /day for 2 weeks with minimal response. Therefore pulse therapy with methyl prednisolone was commenced $30 \mathrm{mg} / \mathrm{kg} /$ day for 3 consecutive days monthly. A good response was seen with lower respiratory rates and better pulse oximetry readings after the first cycle of methylprednisolone (respiratory rate reduced from $70-80 / \mathrm{min}$ to $50-60 / \mathrm{min}$ and $\mathrm{O}_{2}$ saturation at rest increased from $90-91 \%$ to $94-95 \%$ ) and she was discharged from hospital. She will be readmitted monthly for pulse therapy for a minimum of 3-6 months.

\section{Discussion}

ChILD in immunocompetent children is defined as the presence of respiratory symptoms and/or diffuse infiltrates on chest radiographs, abnormal pulmonary function tests with evidence of restrictive ventilatory defect and/or impaired gas exchange, and persistence of any of these findings for $>3$ months $^{2}$. It occurs more commonly in young children $^{3}$. Parental consanguinity is present in about $10 \%$ of children ${ }^{4}$. Failure to thrive is documented in almost two thirds of patients diagnosed before the age of 2 years ${ }^{4}$. Chest X-rays and HRCT scans predominantly show interstitial infiltrates ${ }^{4}$. Oral prednisolone $(1-2 \mathrm{mg} / \mathrm{kg} /$ day) or pulsed intravenous methyl prednisolone, singly or in combination with hydroxychloroquine are the most commonly used drug treatments ${ }^{2}$. The natural history of the disease is very variable and some cases burn out spontaneously even without treatment, whilst others progress relentlessly towards a fatal outcome despite all treatment modalities given ${ }^{5}$.

\section{Acknowledgements}

We thank Dr I N A Gooneratne for doing the High Resolution CT (HRCT) scan of chest.

\section{References}

1. Hagood JS, Com G, Vaughan DJ, Zimmerman J, Young DW, Mroczek-Musulman. Children's Interstitial Lung Disease (ChILD).

Available from: http://www.emedicine.com/ped/topic1950.htm

2. Fan LL, Langston C. Chronic interstitial lung disease in children. Pediatr Pulmonol 1993; 16:184-96.

3. Fan L, Langston C. Paediatric interstitial lung disease. Am J Respir Crit Care Med 2002; 165:1466-7.

4. Task force on chronic interstitial lung disease in immunocompetent children. Eur Resp J 2004; 24: 686-97.

5. Costabel U, King TE. International consensus statement on idiopathic pulmonary fibrosis. Eur Respir J 2001; 17:163-7. 